\title{
Abundance and diversity of decapod crustaceans in the deep-Catalan Sea (Western Mediterranean)
}

\author{
J. E. CARTES and F. SARDÀ \\ Institut de Ciències del Mar, Passeig Nacional s/n, \\ 08039 Barcelona, Spain
}

(Accepted 7 August 1992)

\begin{abstract}
The deep-slope decapod fauna of the Catalan Sea was extensively sampled with an OTSB-14 bottom trawl. A total of 67 bottom tows were taken from 1985 to 1989 at bottom depths ranging from 552 to $2261 \mathrm{~m}$. Species in which abundance decreased with depth were Plesionika acanthonotus, Polycheles typhlops, Calocaris macandreae and Geryon longipes. Highest densities of Acanthephyra eximia, Stereomastis sculpta, and Nematocarcinus exilis were attained at the greatest depths studied. Total abundance, biomass and species richness for decapod crustaceans as a whole decreased with depth. Maximum decapod biomass and diversity occurred on the upper-middle slope on soft bottoms in the Catalan Sea and in all regions for which data were available. In the Catalan Sea, an oligotrophic area, the abundance of decapods as a group seemed to be higher than in northAtlantic eutrophic regions. In these latter areas, other deep-sea benthic invertebrate groups, particularly ophiuroids, predominate.
\end{abstract}

KEYwORDS: Decapod crustaceans, Mediterranean, abundance, biomass, diversity.

\section{Introduction}

The deep-sea decapod crustacean fauna in the Mediterranean has been only qualitatively studied (Carpine, 1970a; Reyss, 1971; Fredj and Laubier, 1985; Pérès, 1985; Abelló and Valladares, 1988; Cartes, 1992 and references cited). Data on abundance, biomass and on the dominant species along the deep slope are particularly scarce.

The structure of bathyal decapod crustacean populations on the upper slope in the northwestern Mediterranean is relatively well known (Zariquiey Alvarez, 1968; Sardà and Palomera, 1981; Abellò et al., 1988) down to a depth of $800 \mathrm{~m}$, with data on species abundance and biomass also available. Below $1000 \mathrm{~m}$ such information is very scarce (Carpine, 1970b; Pérès, 1985; Abelló and Valladares, 1988). The lower subzone is characterized by extremely low species diversity, particularly compared with similar zones in the Atlantic (Pérès, 1985). Qualitative data collected using an Agassiz trawl are available for the region between 1020 and $2011 \mathrm{~m}$ (Abelló and Valladares, 1988). However, the catching power of this gear is low and hence estimation of species abundance using such data is not reliable.

The present paper provides data on the abundance, biomass, and diversity of bathyal decapod species in the Catalan Sea. This has been made possible by extensive sampling of the deep slope with an OTSB-14 bottom trawl at depths ranging from 552 to $2261 \mathrm{~m}$. The results obtained are discussed in the light of the characteristics of 


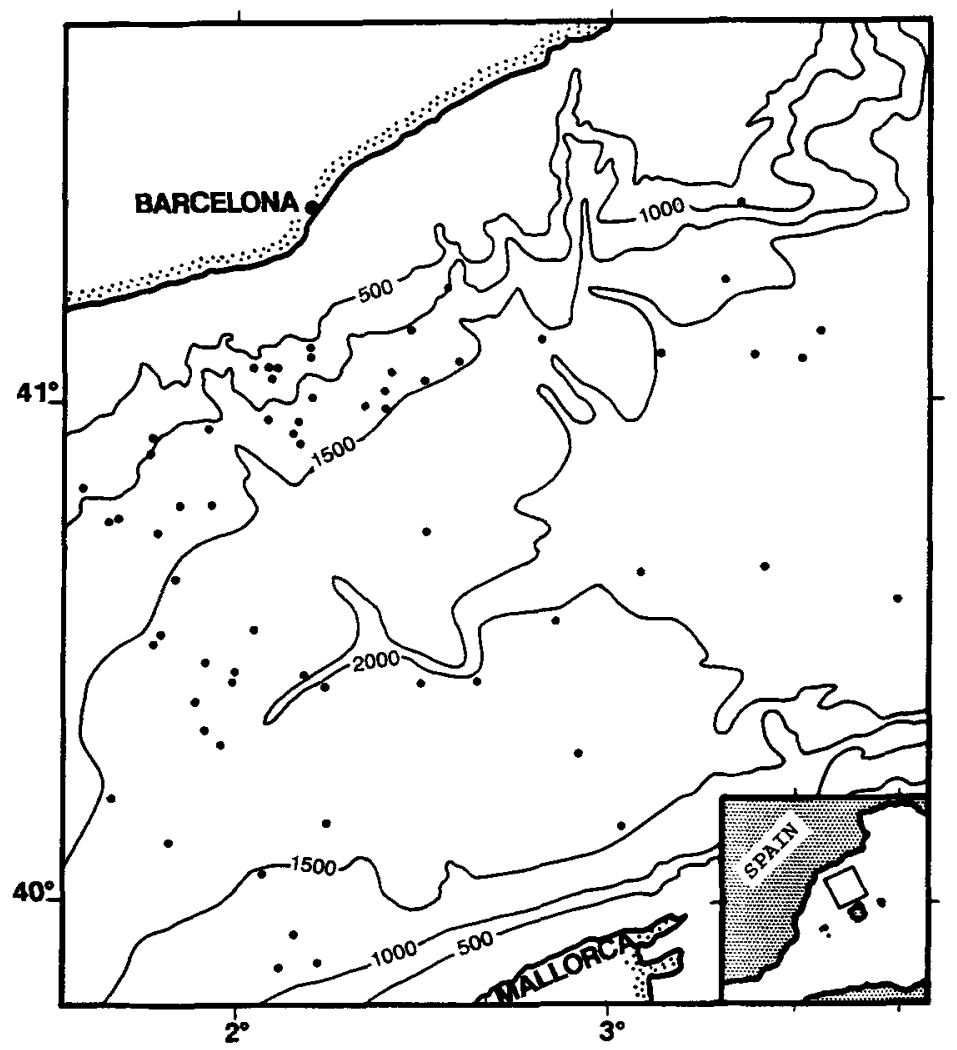

FIG. 1. Location of deep-sea samples (m) collected over the period 1985-1989 using OTSB-14 trawl gear in the Catalan Sea.

the bottom trawl employed and are compared with available data on the deep slope for other oceanic regions.

\section{Materials and methods}

A total of 67 bottom trawls were carried out from 1985 to 1989 at bottom depths ranging from 552 to $2261 \mathrm{~m}$ in the Catalan Sea $\left(38^{\circ} 45 \mathrm{~N}\right.$ to $42^{\circ} \mathrm{N}$ ) (Fig. 1). A detailed description of station data is available in Cartes (1992). Maximum depth in this region is around $2300 \mathrm{~m}$. Physical conditions of the Mediterranean deep-water mass are fairly constant below $200 \mathrm{~m}$ : temperature $12.7^{\circ} \mathrm{C}$ and salinity $38.4 \%$ (Fredj and Laubier, 1985; Hopkins, 1985). Muddy bottoms were dominant along all the slope (Emelyanov, 1972).

All the material included in the present paper was collected with the same sampling gear, an OTSB-14 bottom trawl (headline length $13.7 \mathrm{~m}$ ) equipped with two doors and a single trawl warp (Merrett and Marshall, 1981; Sulak, 1982; Rucabado et al., 1991). The size of the OTSB-14 trawl at a towing speed of 2.6 knots was estimated as a vertical opening of $1.5 \mathrm{~m}$ and a horizontal opening between the wings of $7 \mathrm{~m}$. These measurements were verified with the aid of a remote acoustic sensing system attached to the gear (unpublished data) and were approximately equal to those reported by Sulak (1982). An hour of trawling with the $13.7 \mathrm{~m}$ net at 2.6 knots covers an estimated 
area of $33725 \mathrm{~m}^{2}$ of the sea bottom. The end of the net was covered with a $6 \mathrm{~mm}$ mesh cod-end liner. All the samples were collected on board the R/V Garcia del Cid (engine power: 1500 h.p.; length: $38 \mathrm{~m}$ ). Sampling covered an extensive slope zone (between 862 and $2261 \mathrm{~m}$ ) in which 61 bottom trawls were carried out along the depth transect. An additional six bottom tows were made on the upper middle slope at depths between 552 and $710 \mathrm{~m}$ for purposes of comparison with deeper samples. Although submarine canyons are important in the area all sampling was carried out outside the canyons. A more detailed explanation of sampling design is available in previous works (cf. Rucabado et al., 1991; Stefanescu et al., 1992).

Table 1. List of species collected in the present study.

\begin{tabular}{|c|c|}
\hline Species & Habits \\
\hline Gennadas elegans (S. I. Smith, 1884) & $\mathbf{M}$ \\
\hline Aristeus antennatus (Risso, 1816) & $\mathbf{N}$ \\
\hline Solenocera membranacea (Risso, 1816) & B-E \\
\hline Sergestes articus Kröyer, 1855 & $\mathbf{M}$ \\
\hline Sergestes henseni (Ortmann, 1893) & $\mathbf{M}$ \\
\hline Sergestes sargassi (Ortmann, 1893) & $\mathbf{M}$ \\
\hline Sergia robusta (S. I. Smith, 1882) & $\mathbf{M}$ \\
\hline Richardina fredericii Lo Bianco, 1903 & B \\
\hline Acanthephyra eximia S. I. Smith, 1886 & $\mathrm{~N}$ \\
\hline Acanthephyra pelagica (Risso, 1816) & $\mathbf{M}$ \\
\hline Nematocarcinus exilis (Bate, 1888) & $\mathrm{N}$ \\
\hline Pasiphaea sivado (Risso, 1816) & $\mathbf{M}$ \\
\hline Pasiphaea multidentata Esmark, 1866 & $\mathbf{M}$ \\
\hline Alpheus glaber (Olivi, 1792) & $\mathrm{E}$ \\
\hline Ligur ensiferus (Risso, 1816) & $\mathbf{N}$ \\
\hline Processa canaliculata Leach, 1815 & B-E \\
\hline Pandalina profunda Holthuis, 1946 & $\mathbf{N}$ \\
\hline Plesionika acanthonotus (S. I. Smith, 1882) & $\mathbf{N}$ \\
\hline Plesionika gigliolii (Senna, 1903) & $\mathbf{N}$ \\
\hline Plesionika martia (A. Milne Edwards, 1883) & $\mathrm{N}$ \\
\hline Philocheras echinulatus (M. Sars, 1861) & B \\
\hline Pontocaris lacazei (Gourret, 1887) & B \\
\hline Pontophilus norvegicus (M. Sars, 1861) & B \\
\hline Nephrops norvegicus (Linnaeus, 1758) & B-E \\
\hline Calocaris macandreae Bell, 1864 & $\mathrm{E}$ \\
\hline Axiidae unidentified & $\mathrm{B}-\mathrm{E}$ ? \\
\hline Polycheles typhlops Heller, 1862 & B \\
\hline Stereomastis sculpta (S. I. Smith, 1880) & B \\
\hline Pagurus alatus Fabricius, 1775 & B \\
\hline Pagurus excavatus (Herbst, 1791) & B \\
\hline Munida tenuimana G. O. Sars, 1872 & B \\
\hline Munidopsis tridentata (Esmark, 1857) & B \\
\hline Paromola cuvieri (Risso, 1816) & B \\
\hline Dorhynchus thomsoni Thomson, 1873 & B \\
\hline Macropodia longipes (A. Milne Edwards and Bouvier, 1899) & B \\
\hline Geryon longipes A. Milne Edwards, 1881 & B \\
\hline Chaceon mediterraneus Manning and Holthuis, 1989 & B \\
\hline Macropipus tuberculatus (Roux, 1830) & B \\
\hline Goneplax rhomboides (Linnaeus, 1758) & $\mathrm{E}$ \\
\hline Monodaeus couchi (Couch, 1851) & B-E \\
\hline
\end{tabular}

M: mesopelagic species; N: nektobenthic species; B: benthic species; E: endobenthic species. 


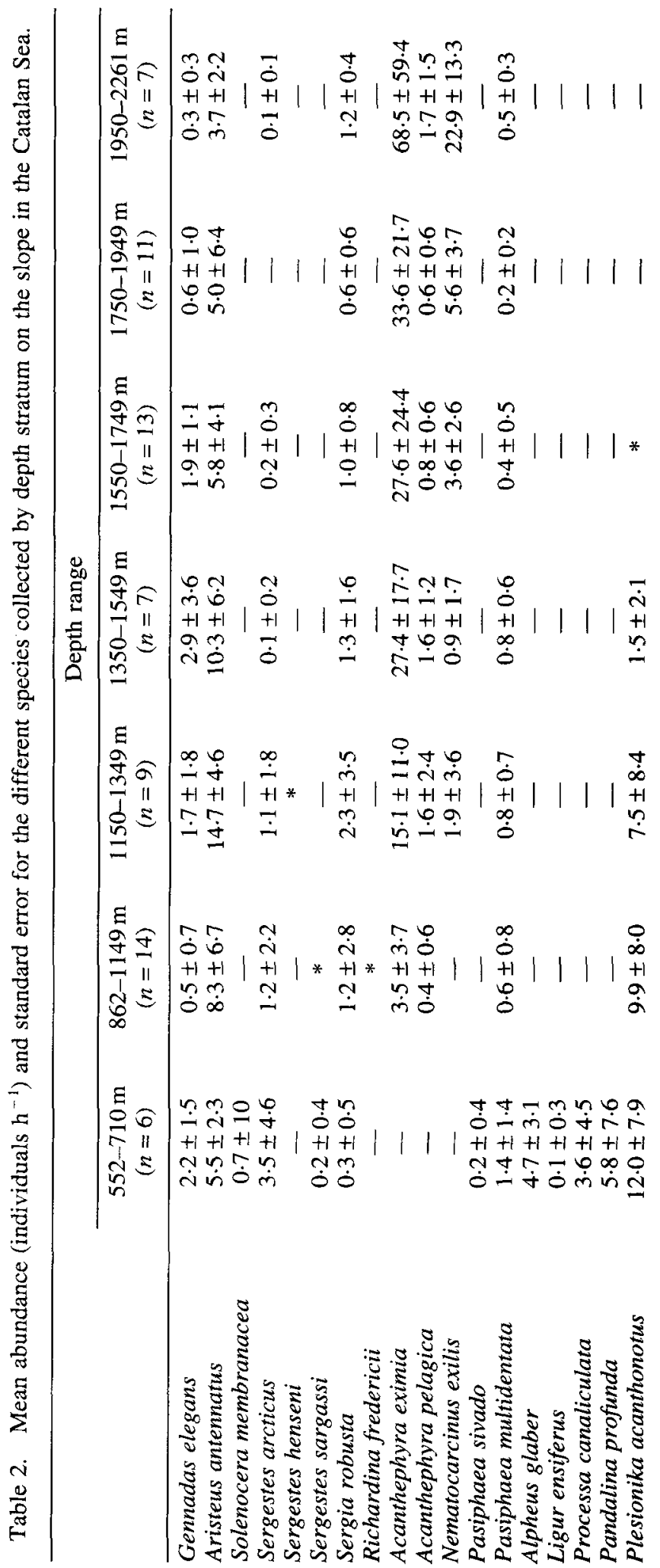




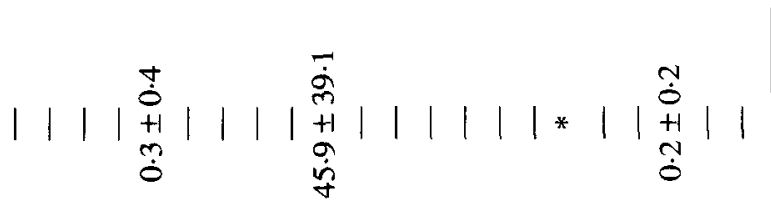

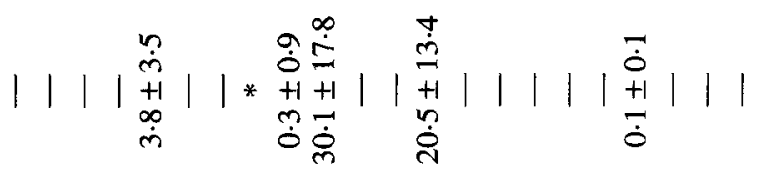

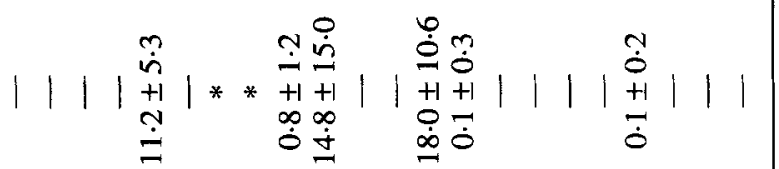

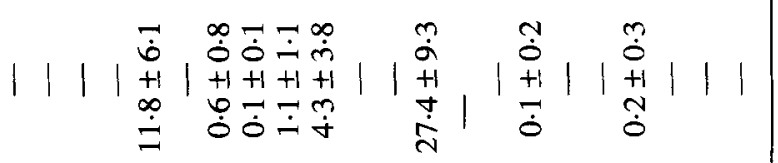

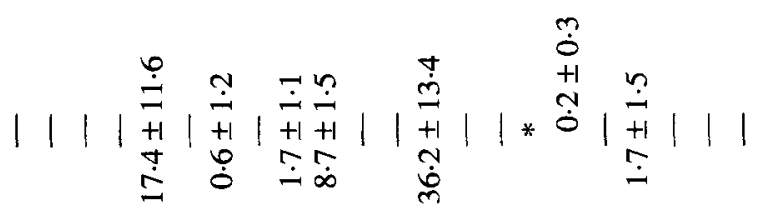

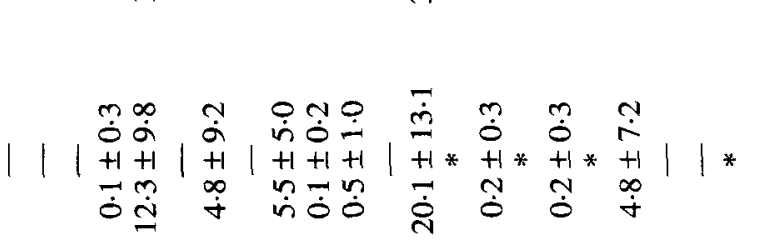

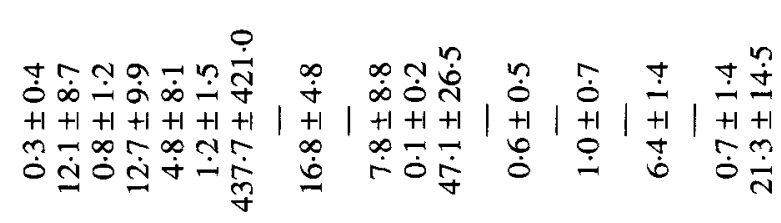

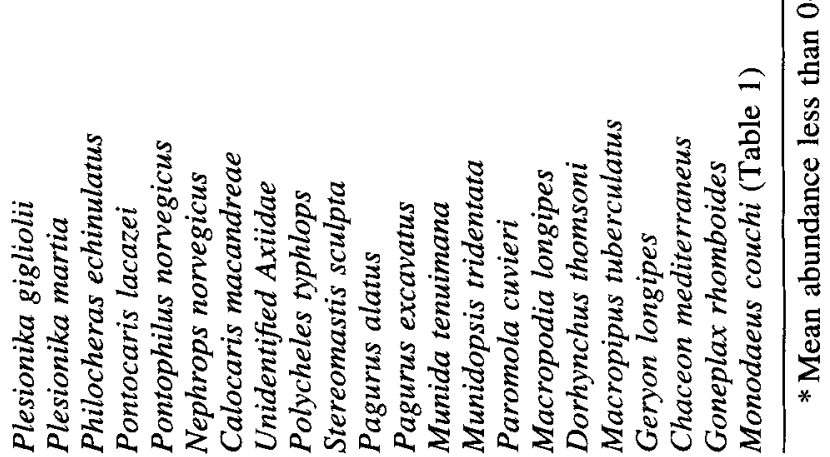




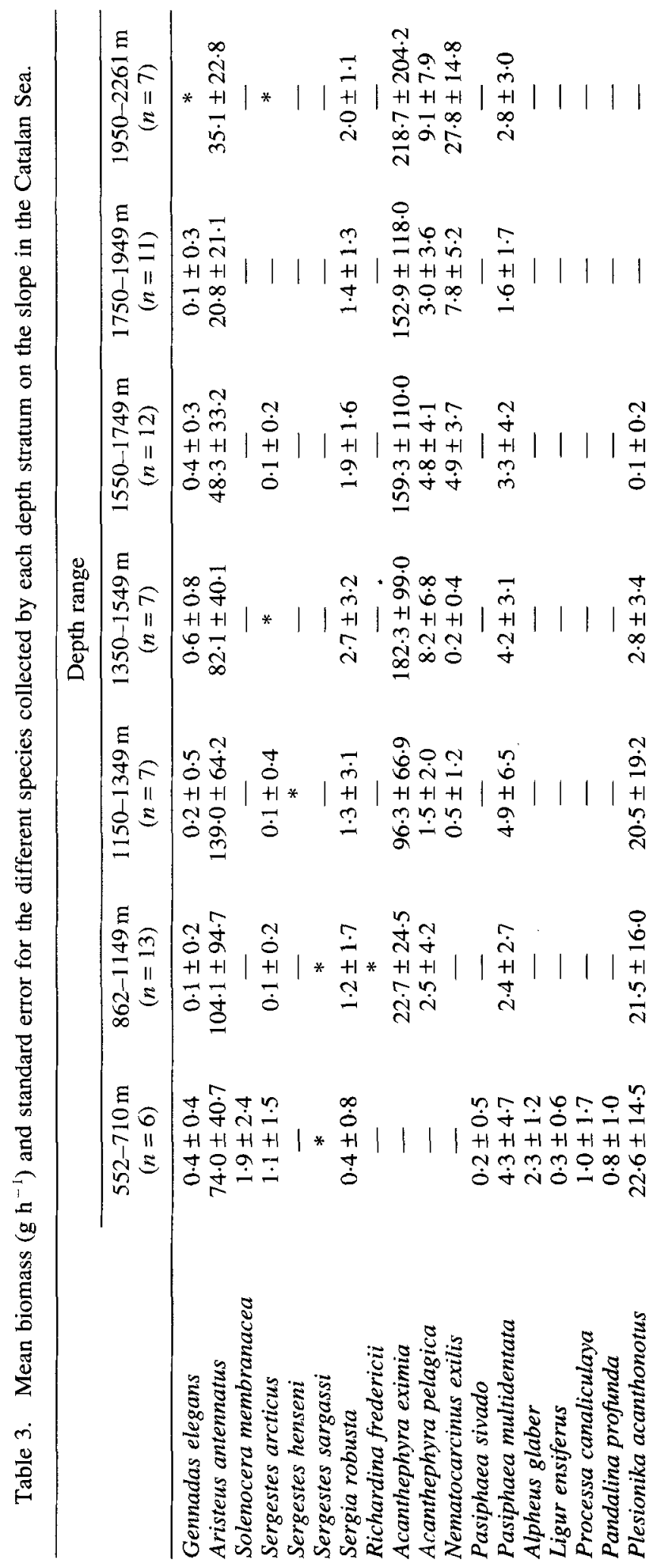




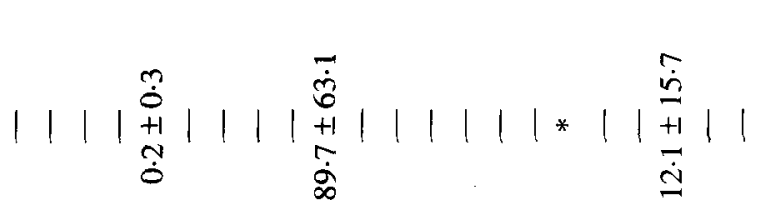

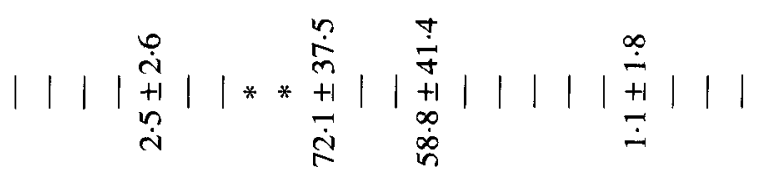

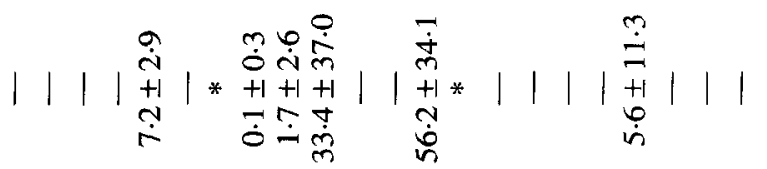

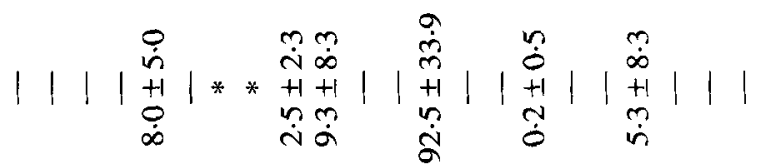

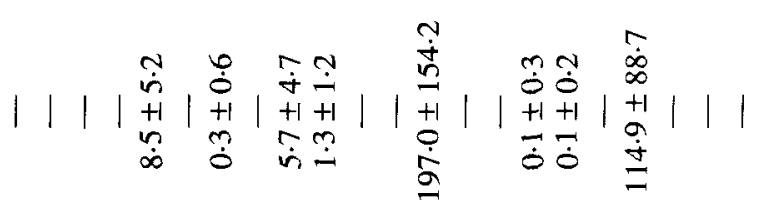

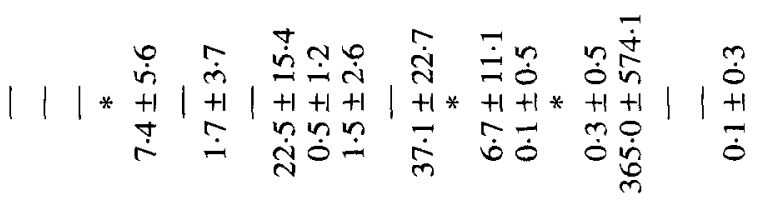

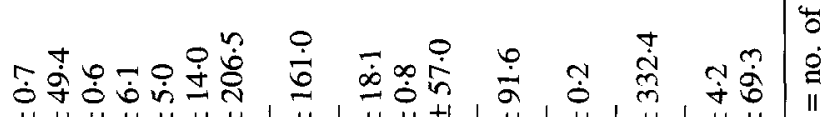

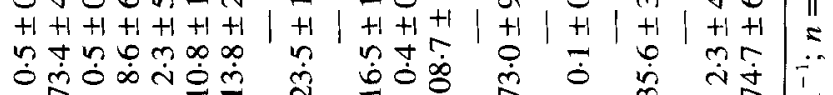

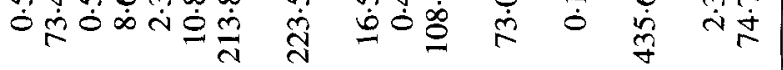

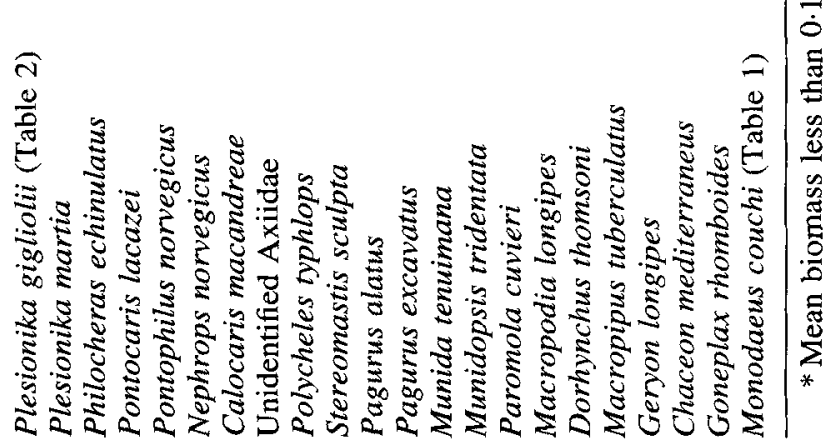


Samples were preserved in $70 \%$ alcohol. Specimens were identified, counted, and weighted at the laboratory. All trawl results were first standardized to $1 \mathrm{~h}$ tows. Abundance (individuals/h) and biomass (grams/h) were calculated by species and for all decapod crustaceans combined for seven arbitrary $200 \mathrm{~m}$ depth strata (between 552 and $2261 \mathrm{~m}$ ), established after sampling. Slope areas were categorized according to the bathymetric zonation previously established in the Catalan Sea decapod communities (Cartes, 1991; Cartes and Sardà, unpublished) as: upper-middle slope (between 552 and $710 \mathrm{~m}$ ); lower-middle slope $(862-1300 \mathrm{~m}$ ); lower slope (below $1300 \mathrm{~m}$ ).

Mean and absolute species richness, diversity (Shannon and Weaver, 1963), and dominance (Simpson, 1949; Magurran, 1988) were calculated for each depth stratum. Abundance and biomass data were transformed $(\ln (x))$ and homogeneity of variances were tested, using a $F_{\max }$ test (Sokal and Rohlf, 1969). Analysis of variance (ANOVA) was used to compare the influence of depth in species richness, abundance and biomass. After this, the significance between the mean species richness, abundance, and biomass values for the different strata was established by a method of multiple comparison of means (Scheffe, 1959).

\section{Results}

The systematic relationships of the species identified in the present study have been published elsewhere (Abelló and Valladares, 1988; Abelló et al., 1988; Cartes, 1993). A list of the species collected is presented in Table 1.

Table 2 sets out the species abundance values by depth stratum, with the number of trawls collected. Species in which abundance declined with depth included Plesionika acanthonotus, Calocaris macandreae, Polycheles typhlops and Geryon longipes. These species were more characteristic of the upper-middle slope communities. Plesionika acanthonotus and $P$. typhlops were abundant in catches made between 600 and $1200 \mathrm{~m}$. From that point, catches fell off to a few isolated individuals at greater depths, with some juvenile $P$. typhlops present at depths down to 1900 (Abello and Cartes, 1992). Calocaris macandreae was relatively abundant only down to about $1000 \mathrm{~m}$, with isolated individuals appearing down to $1300-1500 \mathrm{~m}$. It was the dominant species at $600 \mathrm{~m}$, where it accounted for $70 \%$ of total abundance (Fig. 2). Geryon longipes was abundant between 600 and $1300 \mathrm{~m}$, and only isolated individuals were caught down to $1700-1800 \mathrm{~m}$.

Aristeus antennatus was present over the entire depth range sampled. Below $1000 \mathrm{~m}$ this species showed a peak abundance at $1150-1350 \mathrm{~m}$ and became progressively less abundant particularly below $1500-1600 \mathrm{~m}$. The caridean Pontophilus norvegicus was abundant over a broad depth range from 1000 to $1700 \mathrm{~m}$. The abundance of this species dropped after $1800 \mathrm{~m}$, and it was extremely uncommon at depths of $2000-2200 \mathrm{~m}$. The anomuran Munida tenuimana followed a similar pattern, and abundance values fell off sharply at $1900 \mathrm{~m}$.

The species with the highest densities at great depth included Acanthephyra eximia, Stereomastis sculpta, and Nematocarcinus exilis (Fig. 3). For all these species, maximum abundance levels were recorded in the deepest sampling stratum (below $2000 \mathrm{~m}$ ), and must be considered the dominant species on the lower slope.

Abundance for benthopelagic species was low in all cases. Although demersal trawls are not the best method to sample this species, Merrett (1986) remarks on the contribution made by bottom trawl samplings to our knowledge of pseudoceanic species. In our case, Sergestes articus and Pasiphaea multidentata were more 


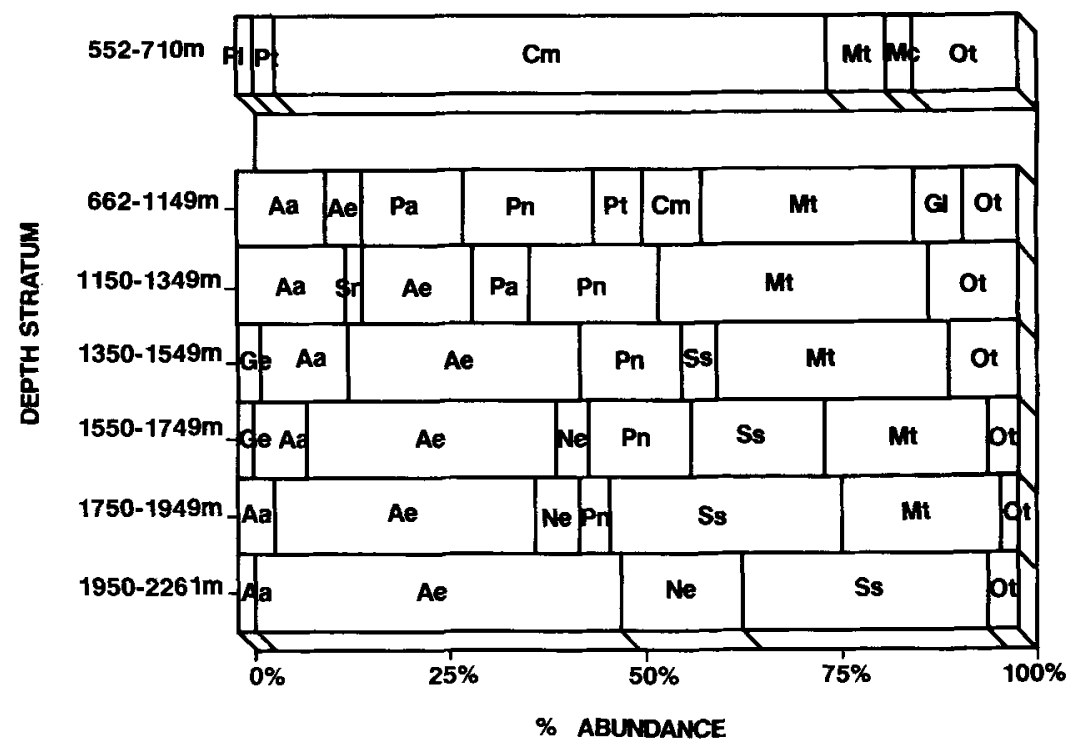

FIG. 2. Relative abundance of dominant species by depth stratum. Aa: A. antennatus; Ae: A. eximia; Cm: C. macandreae; Ge: G. elegans; Gl: G. longipes; Mc: $M$. couchi; Mt: $M$. tenuimana; Ne: $N$. exilis; Ot: Others; Pa: $P$. acanthonotus; Pl: $P$. lacazei; Pn: P. norvegicus; Pt: P. typhlops; Sr: S. robusta; Ss: S. sculpta.

Table 4. Mean total abundance (individuals $\left.\mathrm{h}^{-1}\right)$ and biomass $\left(\mathrm{g} \mathrm{h}^{-1}\right)$ for decapod crustaceans by depth stratum.

\begin{tabular}{ccc}
\hline $\begin{array}{c}\text { Depth range } \\
(\mathrm{m})\end{array}$ & $\begin{array}{c}\text { Mean abundance } \\
\left.\text { (individuals } \mathrm{h}^{-1}\right)\end{array}$ & Mean biomass $\left(\mathrm{g} \mathrm{h}^{-1}\right)$ \\
\hline $552-710$ & $607 \cdot 8 \pm 451 \cdot 9$ & $1352 \cdot 7 \pm 435 \cdot 7$ \\
$862-1149$ & $82 \cdot 5 \pm 36 \cdot 9$ & $667 \cdot 2 \pm 627 \cdot 6$ \\
$1150-1349$ & $116 \cdot 5 \pm 21 \cdot 9$ & $473 \cdot 8 \pm 269 \cdot 9$ \\
$1350-1549$ & $92 \cdot 1 \pm 37 \cdot 4$ & $402 \cdot 1 \pm 144.9$ \\
$1550-1749$ & $91.4 \pm 43 \cdot 6$ & $326 \cdot 8 \pm 146 \cdot 7$ \\
$1750-1949$ & $95 \cdot 5 \pm 46 \cdot 7$ & $301 \cdot 6 \pm 169 \cdot 5$ \\
$1950-2261$ & $145 \cdot 4 \pm 105 \cdot 3$ & $400 \cdot 3 \pm 262 \cdot 5$ \\
\hline
\end{tabular}

abundant at shallower depths, while Acanthephyra pelagica was more abundant on the lower slope.

In terms of biomass the brachyuran $G$. longipes predominated on the middle slope (between 550 and $1349 \mathrm{~m}$ ), due to its high mean weight (Fig. 4, Table 3). Despite its low mean weight, $C$. macandreae was important in terms of biomass on the uppermiddle slope, because of its high abundance. The caridean $A$. eximia was the dominant species in terms of biomass on the lower slope below 1300-1400 m. M. tenuimana was important between 1200 and $1900 \mathrm{~m}$, as was $S$. sculpta at depths greater than $1800 \mathrm{~m}$ (Fig. 4, Table 3).

Mean abundance, biomass and species richness for decapod crustaceans as a whole declined with depth (Tables 4 and 5). Variances were homogeneous in the abundance, 


\section{Acanthephyra eximia}

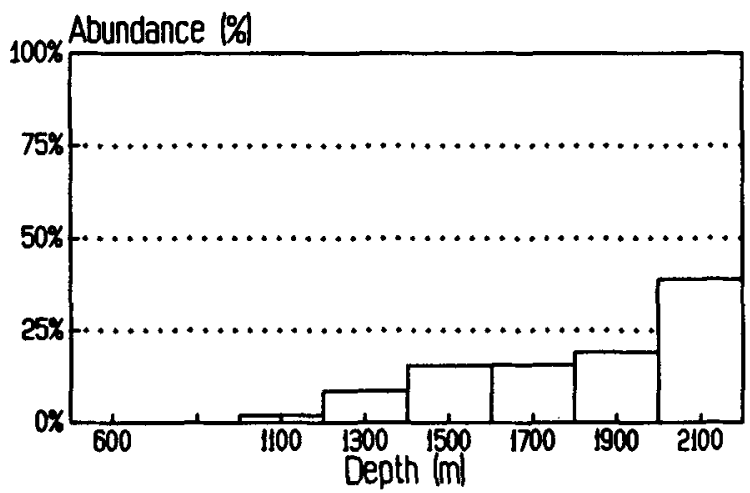

Nematocarcinus exilis

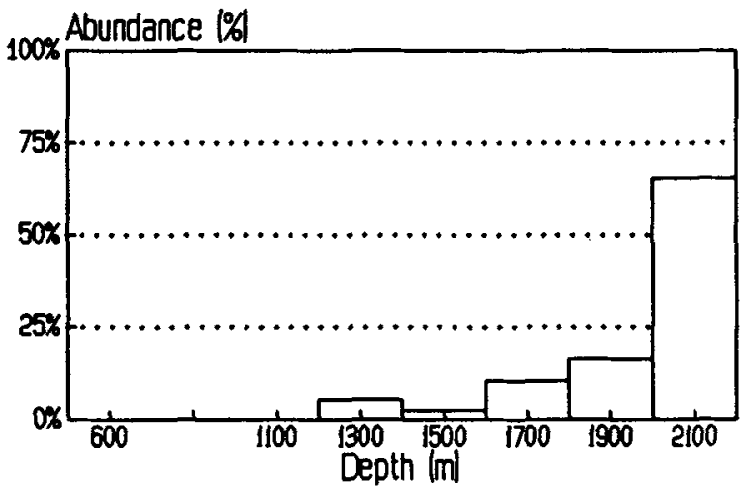

Stereomastis sculpta

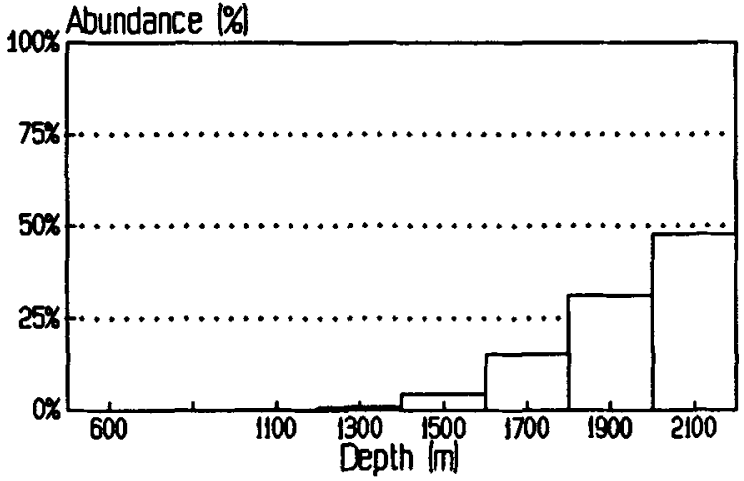

FIG. 3. Distribution of abundance for the three most predominant species on the lower slope.

biomass and species richness data (Table 6), and ANOVA results showed a significant $(P<0.01)$ effect of depth in each case (Table 6). Decline was significant $(P<0.05)$ when abundances values for the interval between 552 and $710 \mathrm{~m}$ were compared with the values below $1000 \mathrm{~m}$ (Table 6). Conversely, abundance increased slightly from 


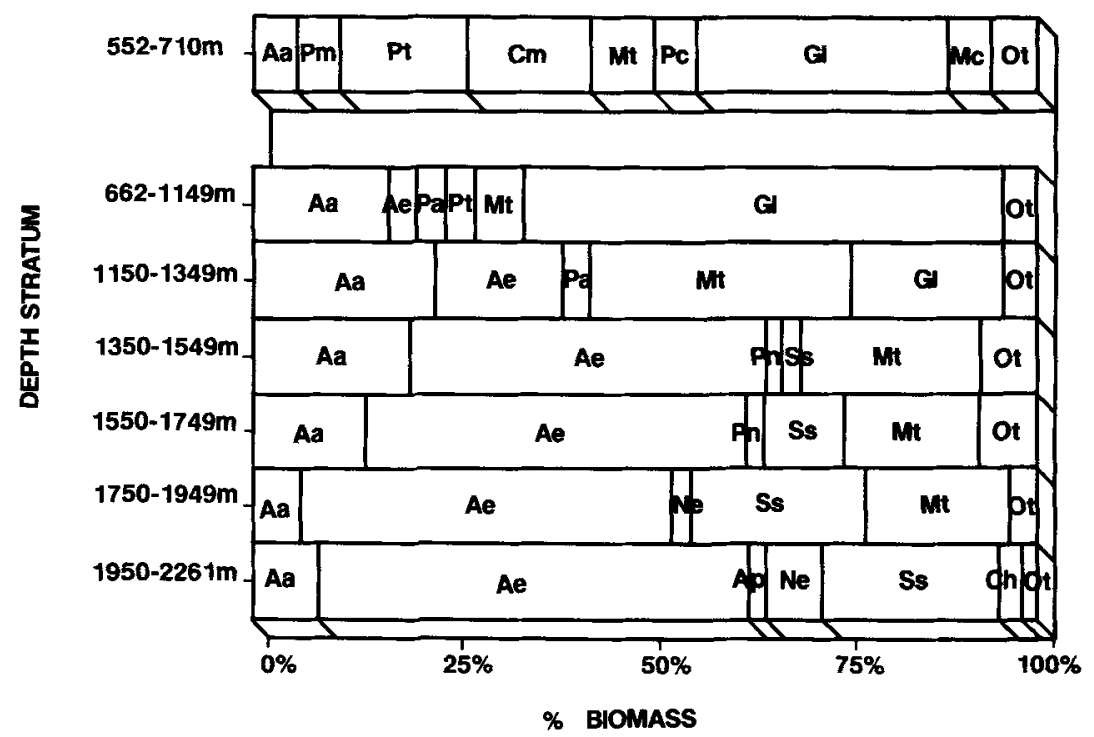

FIG. 4. Relative biomass of dominant species by depth stratum. Aa: A. antennatus; Ae: A. eximia; Ap: A. pelagica; Ch: Ch. mediterraneus; $\mathrm{Cm}$ : C. macandreae; Gl: $G$. longipes; Mc: $M$. couchi; Mt: $M$. tenuimana; Ne: $N$. exilis; Ot: others; Pa: $P$. acanthonotus; Pc: $P$. cuvieri; Pm: P. martia; Pn: P. norvegicus; Pt: $P$. typhlops; Sr: S. robusta; Ss: S. sculpta.

Table 5. Mean number of species, species richness, diversity (Shannon-Wiener index) and dominance (Simpson index) by depth stratum on the slope in the Catalan Sea.

\begin{tabular}{cccccc}
\hline $\begin{array}{c}\text { Depth range } \\
(\mathrm{m})\end{array}$ & $\begin{array}{c}\text { No. of } \\
\text { samples }\end{array}$ & $\begin{array}{c}\text { Mean number } \\
\text { of species }\end{array}$ & $\begin{array}{c}\text { Species } \\
\text { richness }\end{array}$ & $\begin{array}{c}\text { Diversity } \\
\left(H^{\prime}\right)\end{array}$ & $\begin{array}{c}\text { Dominance } \\
\text { (Simpson) }\end{array}$ \\
\hline $552-710$ & 6 & $19.00 \pm 2.76$ & 29 & 1.90 & 0.53 \\
$862-1149$ & 14 & $12.43 \pm 1.72$ & 24 & 3.17 & 0.15 \\
$1150-1349$ & 9 & $12.00 \pm 2.66$ & 21 & 3.18 & 0.21 \\
$1350-1549$ & 7 & $11 \cdot 14 \pm 1.64$ & 19 & 2.72 & 0.21 \\
$1550-1749$ & 13 & $10.54 \pm 1.08$ & 18 & 2.72 & 0.21 \\
$1750-1949$ & 11 & $8.73 \pm 1.54$ & 13 & 2.43 & 0.25 \\
$1950-2261$ & 7 & $8.57 \pm 1.18$ & 14 & 1.82 & 0.33 \\
\hline
\end{tabular}

$2000 \mathrm{~m}$, though the increase was not significant. In terms of biomass significant differences $(P<0.05)$ were found between the values for the upper-middle slope and those for the depth strata below $1350 \mathrm{~m}$ (Table 6). Mean species richness values for the upper-middle slope were significantly different $(P<0.05)$ from the values for depths greater than $1000 \mathrm{~m}$ (Table 6). Differences between the values for the strata from 862 to $1349 \mathrm{~m}$ and the values for the strata at depths greater than $1750 \mathrm{~m}$ were significant in all cases except between the values for the $1150-1349 \mathrm{~m}$ and the $1950-2261 \mathrm{~m}$ strata.

Diversity $(H)$ decreased with depth beyond $1000 \mathrm{~m}$ (Table 5). The values obtained for the upper-middle slope can be attributed in part to methodological causes (underestimation of mobile species), which also account for the dominance values in this same zone (Table 5). 


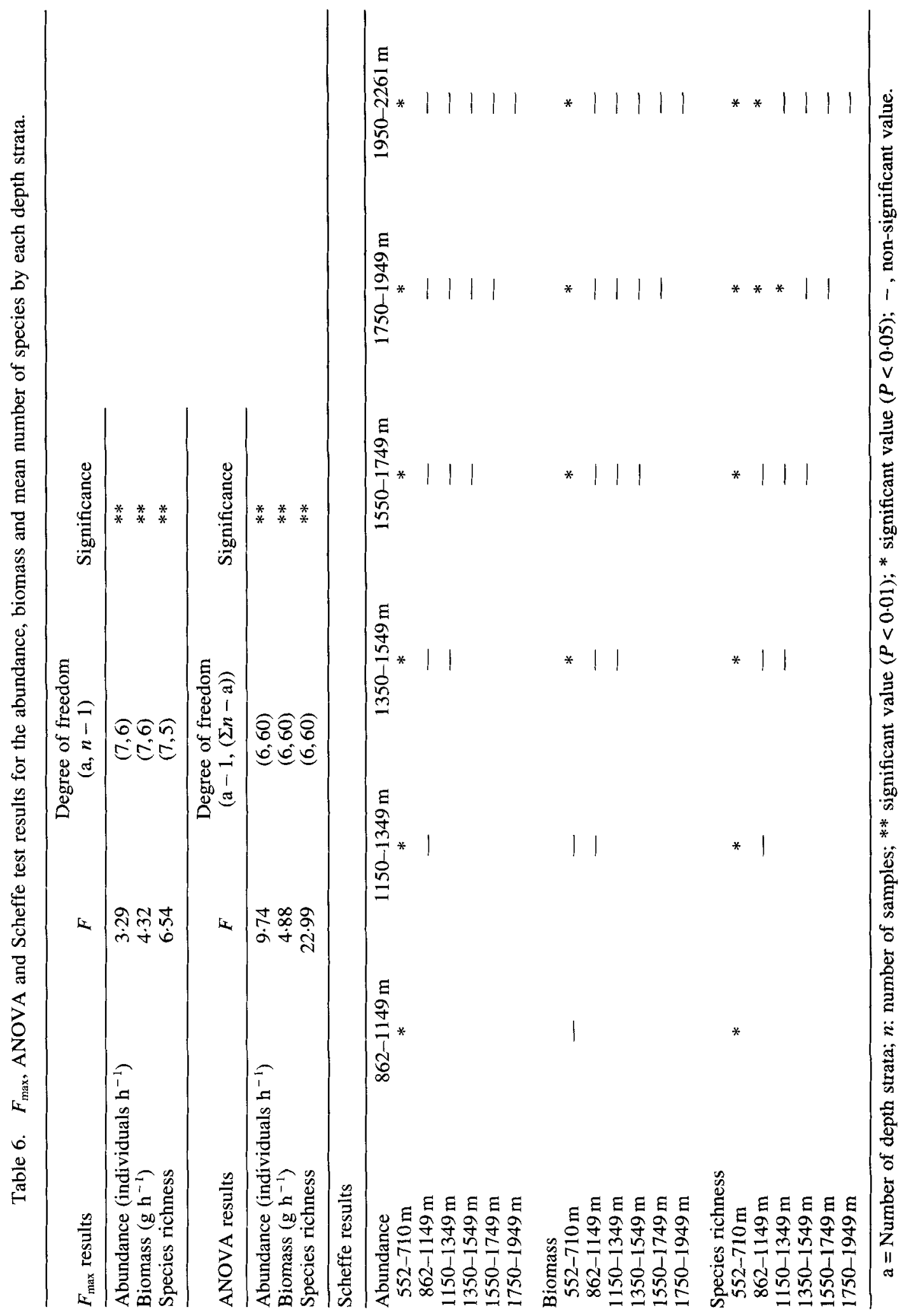




\section{Discussion}

There have been few studies dealing with species abundance in deep-sea megafaunal communities, particularly relating to decapod crustaceans. The reasons for this have been chiefly methodological, i.e. the different types of bottom trawls used and an element of bias towards results on species population density (Gordon and Duncan, 1985; Merrett et al., 1991). The catchability of the OTSB-14 gear is sufficient to justify inclusion of the results on decapod species abundance in the present study.

Changes in species composition along the slope in the Catalan Sea were reflected more by changes in species abundance than species occurrence, in view of the broad depth ranges inhabited by the dominant decapod species in this area (Cartes, 1991, 1993). The most important quantitative boundary was located at around $1200-1300 \mathrm{~m}$, which separated the decapod communities on the middle and lower slopes (Cartes, 1991). The species that displayed the highest abundance values on the middle slope communities (between 550 and $1300 \mathrm{~m}$ ) in the Catalan Sea were Plesionika acanthonotus, Calocaris macandreae, Polycheles typhlops, and Geryon longipes. Plesionika martia, Pontocaris lacazei, and Monodaeus couchii were also abundant on the upper-middle slope. Munida tenuimana and Pontophilus norvegicus, for which the highest abundance was recorded on the middle slope, also attained high densities on the upper part of the lower slope (from 1400 to $1900 \mathrm{~m}$ ). The middle slope is comparable with the middle subzone of Pérès (1985). Aristeus antennatus is especially abundant between 500 and $800 \mathrm{~m}$ in the Western Mediterranean (Maurin, 1962; Pérès, 1985) where it is an important commercial species in fisheries (Tobar and Sardà, 1987). The abundance of this species in the present study on the upper-middle slope was underestimated, due to the small size of the OTSB-14 trawl employed. The most abundant species on the lower slope were Acanthephyra eximia, with Nematocarcinus exilis, and Stereomastis sculpta, which were also cited by Pérès (1985) as the dominant species in the lower subzone.

In the Catalan Sea the characteristics of the gear used may have biased the results for the upper-middle slope. Thus, the abundance of benthopelagic and nektobenthic species in this zone is underestimated by small gear such as the OTSB-14 trawl, down to $1000 \mathrm{~m}$ (Pearcy et al., 1982; Gordon and Duncan, 1985; unpublished data). OTSB-14 trawls are not well-suited to catching bathypelagic species that dwell near the bottom, probably because of their small vertical opening. Thus, when commercial gears, with a larger vertical opening (up to $5 \mathrm{~m}$ ) than the OTSB-14 have been employed, Pasiphaeidae and Sergestidae have been caught in abundance on the upper and middle slope in the Catalan Sea (Abelló et al., 1988; Cartes, 1991). These benthopelagic species play an essential role in the food web of bathyal communities (Lagardère, 1977; Relini-Orsi and Relini, 1990; Cartes, 1991; Cartes and Abelló, 1992). These methodological considerations affected the values for $H^{\prime}$ on the uppermiddle slope and also may explain the high dominance values in this zone, ascribable to the high relative abundance of the burrowing decapod Calocaris macandreae.

Considering the OTSB-14 as a standard gear, results obtained with this trawl in different areas should be comparable (cf. Haedrich and Merrett, 1988). However, comparison of decapod results, especially abundance data, in the different studies poses considerable difficulty in view of the varied methodology employed in sampling (Table 7) and in the presentation of results. Cod-end mesh size is probably the most important aspect affecting results, and in decapod studies the smallest size used (6 mm) would be the most suitable mesh size. Despite all these considerations, the abundance of the benthic genus Stereomastis spp. would seem to be lower in all other areas than 
in the Mediterranean. On the lower slope, Acanthephyra eximia, the dominant species in the Mediterranean, were more abundant than the dominant species in the other zones for which data were available. Off Nova Scotia, total decapod abundance was of the order of half, or even less, that recorded in the Mediterranean, even though samples were collected with a larger bottom trawl (Markle et al., 1988). Off New England (Haedrich et al., 1975, 1980), decapod population densities were always lower than in the Catalan Sea. Decapod density was also negligible on the lower slope in the vicinity of the Rockall Trough (Stefanescu, personal communication 1991).

The absolute biomass values obtained using the OTSB gear were higher (4320-3572 $\mathrm{g} \mathrm{h}^{-1}$ ) on the upper and middle slopes down to $1300 \mathrm{~m}$ in the Northwest Atlantic (Haedrich et al., 1980) than in the Catalan Sea, whereas on the lower slope the values recorded from the Catalan Sea below $2000 \mathrm{~m}$ were of the same order or even higher. On the basis of available comparable data, the abundance and biomass values recorded for deep-sea decapod crustaceans appeared to be higher in the Catalan Sea than the values reported for eutrophic regions in the North Atlantic, particularly on the lower slope (Haedrich et al., 1975, 1980; Wenner and Boesch, 1979; Markle et al., 1988). Arthropod biomass, mainly Geryon ( = Chaceon) quinquedens, was higher on the middle slope than on the lower slope off New England (Haedrich et al., 1975), as was the case for Geryon longipes in the Catalan Sea. Decapod biomass in that same region peaked on the upper slope (283-650 m) and on the middle slope $(653-1290 \mathrm{~m})$, which was attributable to G. quinquedens, whereas the maximum for the megabenthos was between 1380 and $2481 \mathrm{~m}$, linked to fishes and echinoderms, the clearly dominant groups in density and biomass. Decapod crustaceans were also more abundant in the deeper, more oligotrophic zones of the abyssal plain (Sokolova, 1972) between 3879 and $4986 \mathrm{~m}$ in the Atlantic Ocean.

Maximum abundances of decapods were also located on the upper-middle slope in the Middle Atlantic Bight (Wenner and Boesch, 1979) and off Nova Scotia (Markle et al., 1988). In general, all available data point towards higher abundance of decapod crustaceans on soft bottoms on the upper-middle slope, where maximum species richness values were recorded as well.

Decapod abundance seemed to be higher in the Mediterranean than in other regions studied, especially on the lower slope. These results highlight the important role of decapod crustaceans in the deep Mediterranean. Concomitantly, the echinoderm population on the lower slope is low in the Catalan Sea (Fredj and Laubier, 1985; Alvà, 1987). Echinoderms, particularly ophiuroids, are the dominant group in eutrophic zones in the North Atlantic and the Pacific (Rowe and Menzies, 1969; Haedrich et al., 1975, 1980; Smith and Hamilton, 1983; Lampitt et al., 1986). In contrast, ophiuroids are not present on the lower slope in the Mediterranean (Alvà, 1987).

Generally speaking, decapod biomass on the deep slope could be sustained by a high density of benthopelagic organisms (Wishner, 1980; Hargreaves, 1984; Angel, 1990), which would furnish sufficient food, either directly or indirectly, for the communities dwelling in that zone. In neighbouring Atlantic regions (Hargreaves et al., 1984), micronekton densities near the bottom were appreciable down to depths below $2000 \mathrm{~m}$. The level occupied by these organisms should be sufficiently close to the bottom to enable the detritus generated to reach the benthos relatively undegenerated with minimal qualitative change in the organic matter reaching the bottom sediment (Wishner, 1980; Lampitt et al., 1982).

Finally, the patterns observed for diversity with depth were in agreement with the abundance and biomass values. Species richness was highest on the upper-middle 


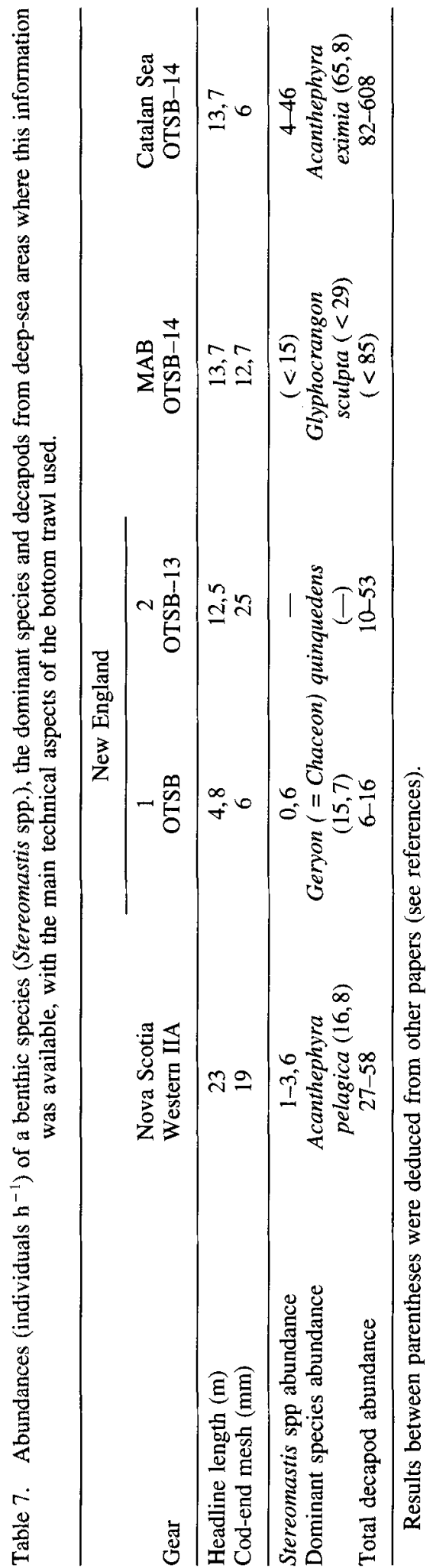




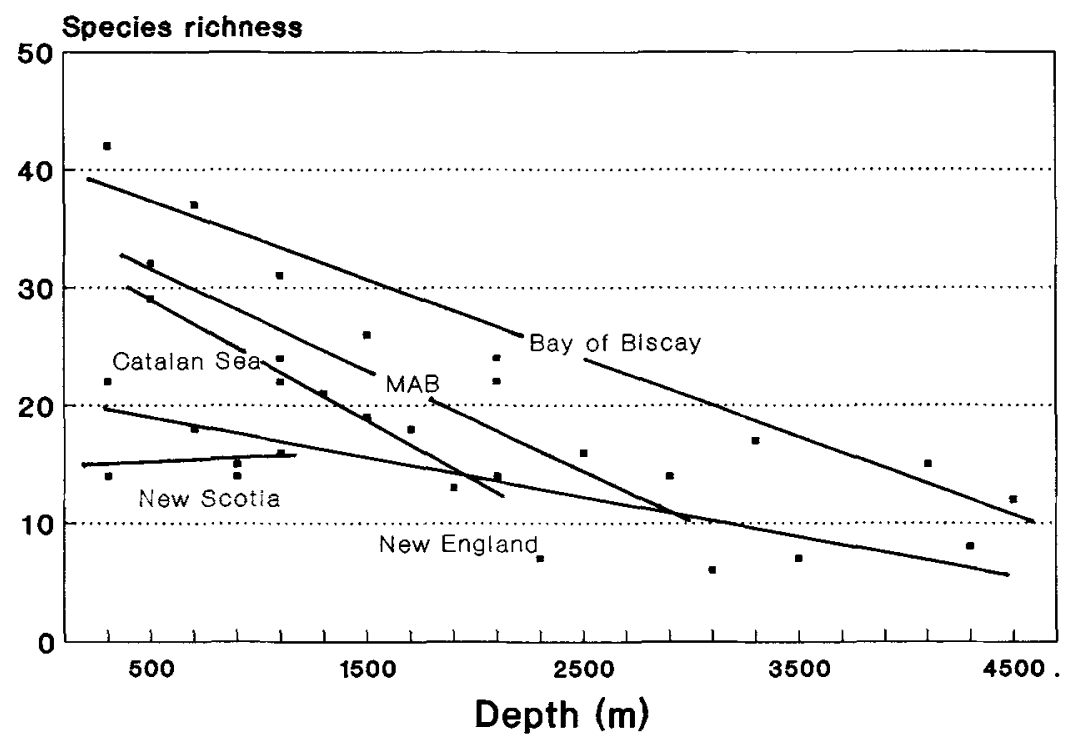

FIG. 5. Species richness by depth in different areas in where deep-sea decapod studies have been carried out.

slope in the Catalan Sea. In decapod crustaceans, species richness is affected by latitude, being highest in tropical regions (Abele, 1982). Thus, species richness in high-latitude regions like the deep-sea zone in the Northwest Atlantic (Haedrich et al., 1980; Markle et al., 1988) is similar to that on the lower slope in the Mediterranean (Fig. 5). When species richness in different regions at similar latitudes is compared (Crosnier and Forest, 1973; Lagardère, 1977; Wenner and Boesch, 1979; Saint Laurent, 1985), the Mediterranean decapod fauna on the lower slope is poorer in both benthic and pelagic species (Foxton, 1970; Crosnier and Forest, 1973; Fasham and Foxton, 1979; Heffernan and Hopkins, 1981; Hargreaves, 1984; Domanski, 1986; Macpherson, 1991). In particular, bathypelagic species are poorly represented in the Mediterranean.

According to the trend in species richness values with depth, maximum decapod crustacean diversity occurs on the upper-middle slope on soft bottoms in all regions for which data are available (Fig. 5). Consideration of the $H^{\prime}$ values is more problematic, since these values are based on the abundance of each species, which is linked to the sampling methods employed. Maximum decapod diversity occurred at intermediate depths, which is in agreement to the findings for other macrofaunal groups (Rex, 1973, 1983; Valentine, 1976; Haedrich et al., 1980), although for decapods the maximum value occurred in shallower zones on the slope.

Bathyal decapod crustaceans may possibly be better adapted to zones that are poor in resources. The large number of empty stomachs found when examining the stomach contents of deep-water species supports this conclusion (Cartes, 1991) as occurred, for instance, in polychelid lobsters, a characteristic deep-sea decapod family (Cartes and Abelló, 1992). A consequence of this would be the predominance of decapods in oligotrophic regions, for instance, the Mediterranean, the Bay of Biscay (Sulak, 1982), or in abyssal zones (Haedrich et al., 1980). In contrast, other deep-sea benthic invertebrate groups, particularly ophiuroids, predominate in more eutrophic zones. 


\section{Acknowledgements}

The authors wish to thank all the members of the Batimar, Abismar, Pont 89 and Pont 90 research projects, to Dr C. Stefanescu (Institut de Ciències del Mar de Barcelona) and Mr W. Norbis for their collaboration, to Mr J. M. Anguita for his technical assistance in preparing the figures and to $\mathrm{Mr} \mathrm{R}$. Sacks for the English translation.

\section{References}

ABELE, L. G., 1982, Biogeography, in D. E. Bliss (ed.), The Biology of Crustacea, Volume 1 (London: Academic Press), pp. 242-304.

Abelló, P. and Valladares, F. J., 1988, Bathyal decapod crustaceans of the Catalan Sea (Northwestern Mediterranean), Mésogée, 48, 97-102.

Abelló, P. and Cartes, J. E., 1992, Population characteristics of the deep-sea lobsters Polycheles typhlops and Stereomastis sculpta (Decapoda, Polychelidae) in the Mediterranean bathyal mud community, Marine Biology, 114, 109-117.

Abelló, P., Valladares, F. J. and Castellon, A., 1988, Analysis of the structure of decapod crustacean assemblages off Catalan coast (North-West Mediterranean), Marine Biology, 98, 39-49.

ALVÁ, V., 1987, Equinodermos batiales de la cubeta catalanobalear (Mediterráneo Noroccidental), Miscel. lània Zoològica, 11, 202-211.

ANGEL, M. V., 1990, Life in the benthic boundary layer: connections to the mid-water and sea floor, Philosophical Transactions of the Royal Society of London, 331, 15-28.

CARPINE, C., 1970a, Ecologie de l'étage bathyal dans la Méditerranée occidentale, Memoires de l'Institut Océanographique de Monaco, 2, 1-146.

CARPINE, C. 1970b, Une expérience de chalutage profond (recherche de la 'Caravelle' engloutie au large de Nice), Bulletin de l'Institut Océanographique de Monaco, 69, (1408), 1-16.

CARTES, J. E., 1991, Análisis de las comunidades y estructura trófica de los Crustáceos Decápodos batiales del Mar Catalán, Thesis, Universidad Politécnica de Catalunya, $627 \mathrm{pp}$.

CARTES, J. E., 1992, Deep-sea decapod fauna of the Western Mediterranean: bathymetric distribution and biogeographic aspects, Crustaceana (In press).

CARTES, J. E. and Abello, P., 1992, Comparative feeding habits of polychelid lobsters in the Western Mediterranean deep-sea communities, Marine Ecology Progress Series, 84, 139-150.

Crosner, A. and Forest, J., 1973, Les crevettes profondes de l'Atlantique oriental tropical, Faune Tropicale, 19, 1-409.

DoMANSKI, P., 1986, The near-bottom shrimp faunas (Decapoda: Natantia) at two abyssal sites in the Northeast Atlantic Ocean, Marine Biology, 93, 171-180.

Emelyanov, E. M., 1972, Principal types of recent bottom sediments in the Mediterranean Sea: their mineralogy and geochemistry, in D. J. Stanley (ed.), The Mediterranean Sea: a natural sedimentation laboratory (Stroudsburg: Dowden, Hutchinson \& Ross), pp. 355-386

FASHAM, M. J. R. and FoxTON, P., 1979, Zonal distribution of pelagic Decapoda (Crustacea) in the eastern north Atlantic and its relation to the physical oceanography, Journal of Experimental Marine Biology and Ecology, 37, 225-253.

FoXTON, P., The vertical distribution of pelagic decapods (Crustacea: Natantia) collected on the SOND Cruise 1965. I. The Caridea, Journal of the Marine Biological Association of the United Kingdom, 50, 939-960.

FredJ, G. and LAuBIER, L., 1985, The deep Mediterranean benthos, in M. MoraitouApostolopoulou and V. Kiortsis (eds), Mediterranean Marine Ecosystems (New York and London: Plenum Press), pp. 109-146.

Gordon, J. D. M. and Duncan, J. A. R., 1985, The ecology of the deep-sea benthic and benthopelagic fish on the slopes of the Rockall Trough, northeastern Atlantic, Progress in Oceanography, 15, 37-69.

HAEDRICH, R. L. and MERRETT, N. R., 1988, Summary atlas of deep-living demersal fishes in the North Atlantic Basin, Joumal of Natural History, 22, 1325-1362. 
HAedrich, R. L., Rowe, G. T. and Polloni, P. T., 1975, Zonation and faunal composition of epibenthic populations on the continental slope south of New England, Journal of Marine Research, 33, 191-212.

Haedrich, R. L., Rowe, G. T. and Polloni, P. T., 1980, The megabenthic fauna in the Deep-Sea South of New England, USA, Marine Biology, 57, 165-179.

Hargreaves, P. M., 1984, The distribution of Decapoda (Crustacea) in the open ocean and near-bottom over an adjacent slope in the northern North-east Atlantic ocean during Autumn 1979, Journal of the Marine Biological Association of the United Kingdom, 64, 829-857.

Hargreaves, P. M., Ellis, C. J. and ANGel, M. V., 1984, An assessment of biological processes close to the sea bed in a slope region and its significance to the assessment of sea bed disposal of radioactive waste, Institute of Oceanographic Sciences, Wormley, UK, unpublished Report 185, 121 pp.

HEFFERNAN, J. J. and HoPKINS, T. L., 1981, Vertical distribution and feeding of the shrimp genera Gennadas and Bentheogennema (Decapoda: Penaeidea) in the Eastern Gulf of Mexico, Journal of Crustacean Biology, 1 (4), 461-473.

HoPkINS, T. S., 1985, Physics of the sea, in R. Margalef (ed.), Key Environments: Western Mediterranean (New York: Pergamon Press), pp. 100-125.

LaGardère, J. P., 1973, Distribution des décapodes dans le sud du golfe de Gascogne, Revue des Travaux de l'Institut de Pêches maritimes, 37 (1), 77-95.

LAGARDÈRE, J. P., 1977, Recherches sur la distribution verticale et sur l'alimentation des crustaces decapodes benthiques de la Pene Continentale du Golfe de Gascogne. Analyse des groupements carcinologiques, Bulletin du Centre d'Etudes et de Recherche scientifique de Biarritz, 11 (4), 367-440.

LAMPITT, R. S., BILleTt, D. S. M. and RICE, A. L., 1986, Biomass of the invertebrate megabenthos from 500 to $4100 \mathrm{~m}$ in the north-east Atlantic Ocean, Marine Biology, 93, 69-81.

MACPHERSON, E., 1991, Biogeography and community structure of the decapod crustacean fauna off Namibia (Southeast Atlantic), Journal of Crustacean Biology, 11 (3), 401-415.

Magurran, A. E., 1988, Ecological Diversity and its Measurement (London: Croom Helm), 179 pp.

Markle, D. F., Dadswell, M. J. and Halliday, R. G. , 1988, Demersal fish and decapod crustacean fauna of the upper continental slope off Nova Scotia from La Have to $\mathrm{Sr}$. Pierre Banks, Canadian Journal of Zoology, 66, 1952-1960.

Maurin, C., 1962, Etude des fons chalutables de la Mediterranée occidentale (Ecologie et Pêche). Resultats des campagnes des navires océanographiques 'President Theodore Tissier', 1957-1960, et 'Thalassa', 1960-1961, Revue des trevaux de l'Institut de Pêches maritimes, 26 (2), 163-218.

MERRETT, N. R., 1986, Biogeography and the oceanic rim: a poorly known zone of ichthyofaunal interaction, in Pelagic Biogeography, UNESCO technical papers in marine science, UNESCO, pp. 201-208.

Merrett, N. R. and Marshall, N. B., 1981, Observations on the ecology of deep-sea bottomliving fishes collected off northwest Africa $\left(08^{\circ}-27^{\circ} \mathrm{N}\right)$, Progress in Oceanography, 9 , 185-244.

Merrett, N. R., Gordon, J. D. M., Stehmann, M. and Haedrich, R. L., 1991, Deep demersal fish assemblage structure in the Porcupine Seabight (eastern North Atlantic): slope sampling by three different trawls compared, Journal of the Marine Biological Association of the United Kingdom, 71 (2), 329-358.

Pearcy, W. G., Stein, D. L. and Carney, R. S., 1982, The deep-sea benthic fish fauna of the northeastern Pacific Ocean on Cascadia and Tufts Abyssal Plains and adjoining continental slopes, Biological Oceanography, 1, 375-428.

PÉRÈs, J. M., 1985, History of the Mediterranean Biota and the Colonization of the Depths, in R. Margalef (ed.), Key Environments: Western Mediterranean (New York: Pergamon Press), pp. 198-232.

Relini-Orsi, L. and Relini, G., 1990, The glass shrimp Pasiphaea sivado in the food chains of the Ligurian Sea, in M. Barnes and N. Gibson (eds), Tropic Relationships in the Marine Environment. Proceedings of the 24th European Marine Biology Symposium (Aberdeen: Aberdeen University Press), pp. 334-346. 
REX, M. A., 1973, Deep-sea species diversity: decreased gastropod diversity at abyssal depths, Science, 181, 1051-1052.

ReX, M. A., 1983, Geographic patterns of species diversity in the deep-sea benthos in G. T. Rowe (ed.) The Sea: Deep-Sea Biology, Volume 8 (New York: John Wiley \& Sons), pp. $453-472$.

Reyss, D., 1971, Les canyons sous-marins de la mer Catalane: le rech du Cap et le rech Lacaze-Duthiers. III. Les peuplements de macrofaune benthique, Vie et Milieu, 22, $529-613$.

Rowe, G. T. and MENZIEs, R. J., 1969, Zonation of large benthic invertebrates in the deep-sea off the Carolinas, Deep-Sea Research, 16, 531-537.

Rucabado, J., Lloris, D. and Stefanescu, C., 1991, OTSB-14: Un arte de arrastre bentónico para la pesca profunda (por debajo de los $1000 \mathrm{~m}$, Informes Técnicos de Scientia Marina, $165,1-27$.

SAINT LAURENT, M., 1985, Remarques sur la distribution des crustacés décapodes, in L. Laubier and C. Monniot (eds), Peuplements profonds du golfe de Gascogne (Brest: Ifremer), pp. 469-478.

SARDÀ, F. and PAlomera, I., 1981, Crustáceos decápodos capturados durante la campaña 'Mediterráneo Il' (Marzo, 1977) en el Mar Catalán, Resultados de las Expediciones Cientificas (Suplemento) Investigación Pesquera, 9, 143-150.

SCHEFFE, H., 1959, The Analysis of Variance (New York: John Wiley), 477 pp.

Shannon, C. E. and WeAver, W., 1963, The Mathematical Theory of Communication (Urbana: University of Illinois Press), $117 \mathrm{pp}$.

Simpson, E. H., 1949, Measurement of diversity, Nature, 163, 680-688.

SMith, C. R. and HAMILTON, S. C., 1983, Epibenthic megafauna of a bathyal basin off southern California: patterns of abundance, biomass, and dispersion, Deep-Sea Research, 30 (9A), 907-928.

SoKal, R. R. and RoHLF, F. J., 1969, Biometría. Principios y métodos estadísticos en la investigación biológica (Madrid: H. Blume Ediciones), $832 \mathrm{pp}$.

Sokolova, M. N., 1972, Trophic Structure of Deep-Sea macrobenthos, Marine Biology, 16, $1-12$.

STEFAnESCu, C., Lloris, D. and Rucabado, J., 1992, Deep-living demersal fishes in the Catalan Sea (western Mediterranean) below a depth of $1000 \mathrm{~m}$, Journal of Natural History, 26, 197-213.

SUlAK, K. J., 1982, A comparative taxonomic and ecological analysis of temperate and tropical demersal deep-sea fish faunas in the western North Atlantic, Ph.D dissertation, University of Miami, $211 \mathrm{pp}$.

TOBAR, R. and SARDÀ, F. 1987, Análisis de las capturas de gamba rosada, Aristeus antennatus (Risso, 1816) en los últimos decenios en Cataluña, Informes Técnicos del Instituto de Ciencias del Mar de Barcelona, 142, 1-20.

Valentine, J. W., 1976, Genetic strategies of adaptation, in F. J. Ayala (ed.), Molecular Evolution (Sunderland, Massachusetts: Sinauer Associates), pp. 78-94.

WENNER, E. L. and BOESCH, D. F., 1979, Distribution patterns of epibenthic decapod Crustacea along the shelf-slope coenocline, middle Atlantic Bight, USA, Bulletin of the Biological Society of Washington, 3, 106-133.

WiSHNER, K. F., 1980, The biomass of the deep-sea benthopelagic plankton, Deep-Sea Research, 27A, 203-216.

Zariquiey Alvarez, R., 1968, Crustáceos Decápodos Ibéricos, Investigación Pesquera, 32, $1-510$. 